\title{
ANALISIS SISTEM DAN PROSEDUR PEMUNGUTAN PAJAK KENDARAAN BERMOTOR DAN BEA BALIK NAMA KENDARAAN BERMOTOR PADA BADAN PENDAPATAN DAERAH PROVINSI SULAWESI UTARA
}

\author{
Angraini Puspita Kalalo ${ }^{1}$, Ventje Ilat $^{2}$, Dhullo Afandi ${ }^{3}$ \\ 1,2,3 Jurusan Akuntansi, Fakultas Ekonomi dan Bisnis, Universitas Sam Ratulangi, Jl. Kampus Bahu, Manado, \\ 95115, Indonesia \\ E-mail: anggikalalo15@gmail.com
}

\begin{abstract}
North Sulawesi Province levies five provincial taxes, two of which are PKB and BBN-KB which levied based on the determination of the regional head. This study aims to determine the adequacy of the system and procedures for collecting PKB and BBN-KB in the Province of North Sulawesi. The method used in this research is qualitative. The results of the study showed that the manual payment system and procedures were in accordance with applicable regulation namely Regional Regulation No.7 of 2011 article 52, while for the payment system and procedures through assitive device (dhrive thru) and online were not in accordance with applicable regulation. Then for the internal control analysis system of the procedures for collecting PKB and BBN-KB carried out by BAPENDA, North Sulawesi Province is in accordance with the apllicable internal control concept.
\end{abstract}

Keywords: system and procedure; motor vehicle taxes; motor vehicle transfer fees; regulation; internal controls

\section{PENDAHULUAN}

Pajak adalah hal terpenting bagi sebagian negara, karena pajak adalah sumber utama pendapatan negara. Jika pajak tidak diberlakukan maka kegiatan negara akan mengalami kesulitan. Penggunaan uang pajak seperti dari belanja pegawai sampai dengan pembiayaan proyek-proyek pembangunan. Uang pajak juga dapat digunakan untuk pembiayaan dalam rangka untuk memberikan rasa nyaman pada masyarakat dan juga masyarakat dapat menikmati fasilitas yang diberikan oleh pemerintah yang biayanya berasal dari pajak masyarakat yang teratur dalam membayar pajak. Pajak adalah pungutan wajib yang dibayar rakyat untuk negara dan akan digunakan untuk kepentingan pemerintah dan masyarakat umum. Rakyat yang membayar pajak tidak akan merasakan manfaat dari pajak secara langsung, karena pajak digunakan untuk kepentingan umum, bukan untuk kepentingan pribadi. Pajak merupakan tagihan atau iuran yang harus dipenuhi oleh setiap orang atau masyarakat.

Pajak berdasarkan kewenangannya, dapat dibedakan dalam 2 bagian yaitu pajak pusat dan pajak daerah. Pajak pusat yaitu pajak yang dipungut oleh pemerintah pusat dan digunakan untuk membiayai rumah tangga negara. Sedangkan pajak daerah yaitu pajak yang dipungut oleh pemerintah daerah dan digunakan untuk membiayai rumah tangga daerah. Mengenai pajak daerah, peranannya juga sangat penting sebagai sumber pendapatan daerah dan sebagai sumber penopang daerah pembangunan daerah, karena pajak daerah merupakan salah satu sumber pendapatan daerah. Pemerintah daerah telah mendapatkan izin untuk melaksanakan pemungutan pajak daerah guna memberikan peluang kepada daerah agar dapat menggali secara maksimal yang ada di daerahnya, dengan memperhatikan ekonomi dan sosial daerah serta unsur legalitasnya. Pajak daerah yang diizinkan adalah pajak provinsi yaitu, pajak kendaraan bermotor, bea balik nama kendaraan bermotor, pajak bahan bakar kendaraan bermotor, pajak air permukaan, dan pajak rokok. Langkah yang dijalankan 
pemerintah untuk penerimaan pajak yaitu dengan diberlakukan undang-undang perpajakan yang baru dikenal dengan istilah reformasi pajak (tax reform).

Badan Pendapatan Daerah (BAPENDA) Provinsi Sulawesi Utara berfungsi sebagai terkoordinasinya kegiatan yang berhubungan yaitu, pemungutan pajak, pengumpulan dan penerimaan daerah yang berasal dari pajak daerah, pendapatan asli daerah dan retribusi daerah. Dengan demikian Badan Pendapatan Daerah (BAPENDA) Provinsi Sulawesi Utara merupakan pusat informasi mengenai tata kerja dan hubungan kerja antara dinas teknis yang menjalankan kegiatan yang berkaitan dengan pemungutan, pengumpulan dan penerimaan sumber pendapatan daerah. Pemungutan pajak kendaraan bermotor dan bea balik nama kendaraan bermotor yang dijalankan oleh badan pendapatan daerah. Terdapat 3 alternatif pembayaran yang diberlakukan oleh Badan Pendapatan Daerah (BAPENDA) Provinsi Sulawesi Utara yaitu alternatif pembayaran secara manual di Samsat Manado, alternatif pembayaran melalui Samsat bantu yang mulai beroperasi pada tahun 2013 dan alternatif pembayaran melalui online pada tahun 2017.

\section{TINJAUAN PUSTAKA}

Menurut Mardiasmo (2018:3) pengertian pajak adalah iuran rakyat yang kepada kas negara berdasarkan undang-undang dengan tiada mendapat jasa timbal yang langsung dapat ditunjukkan dan digunakan untuk membayar pengeluaran umum. Menurut Purwono (2010:13), syarat pemungutan pajak dibedakan menjadi 5 yaitu: syarat keadilan, syarat yuridis, syarat ekonomis, syarat finansial, dan syarat sederhana. Undang-Undang Nomor 16 Tahun 2009 tentang ketentuan umum dan tata cara perpajakan adalah pajak adalah konstribusi wajib pajak kepada negara yang terutang oleh orang pribadi atau badan yang bersifat memaksa berdasarkan undang-undang, dengan tidak mendapatkan imbalan secara langsung dan digunakan untuk keperluan negara bagi sebesar-besarnya kemakmuran rakyat.

Tarif pajak menurut Supramono dan Damayanti (2010:7) yaitu tarif pajak digunakan dalam perhitungan besarnya pajak terutang. Dengan kata lain tarif pajak merupakan tarif yang digunakan untuk menentukan besarnya pajak yang harus dibayar. Menurut Mardiasmo (2018:14) berdasarkan pengertian atau istilah yang terkait dengan pajak daerah antara lain:

1. Daerah otonom, selanjutnya disebut daerah, adalah kesatuan masyarakat hukum yang mempunyai batas-batas wilayah yang berwewenang mengatur dan mengurus urusan pemerintah dan kepentingan masyarakat setempat menurut prakarsa sendiri berdasarkan aspirasi masyarakat dalam sistem.

2. Pajak daerah, yang selanjutnya disebut pajak, adalah kontribusi wajib kepada daerah yang terutang oleh orang pribadi atau badan yang bersifat memaksa berdasarkan undangundang, dengan baik mendapatkan imbalan secara langsung dan digunakan untuk keperluan daerah bagi sebesar-besarnya kemakmuran rakyat.

3. Badan, adalah sekumpulan orang atau modal yang merupakan kesatuan, baik yang melakukan usaha maupun yang tidak melakukan usaha yang meliputi perseroan terbatas, perseroan komanditer, perseroan lainnya, badan usaha milik negara, atau badan usaha milik daerah, dengan nama dan dalam bentuk apapun, firma, kongsi, koperasi, dana pensiun, persekutuan, perkumpulan, yayasan, organisasi masa, organisasi sosial politik, atau organisasi lainnya, lembaga dan bentuk badan lainnya termasuk kontrak investasi kolektif dan bentuk usaha tetap.

4. Subjek pajak, adalah orang pribadi atau badan yang dapat dikenakan pajak.

5. Wajib pajak, adalah orang pribadi atau badan, meliputi pembayar pajak, pemotong pajak, dan pemungut pajak, yang mempunyai hak dan kewajiban perpajakan sesuai dengan ketentuan peraturan perundang-undangan.

Menurut Damas (2017:118), pajak kendaraan bermotor adalah pajak atas kepemilikan dan penguasaan kendaraan bermotor. Kendaraan bermotor yang dimaksud adalah semua 
kendaraan beroda beserta gandengannya yang digunakan di semua jenis jalan darat, dan lainnya yang berfungsi untuk mengubah suatu sumber daya energi tertentu menjadi tenaga gerak kendaraan bermotor yang bersangkutan, termasuk alat berat dan alat besar yang dalam operasinya menggunakan roda dan motor dan tidak melekat secara permanen serta kendaraan bermotor yang dioperasikan di air. Undang-Undang Nomor 28 Tahun 2009 mengatur tentang pemungutan pajak kendaraan bermotor dalam pasal 3 sampai pasal 8.

Menurut Siahaan (2010:246), bea balik nama kendaraan bermotor adalah pajak atas penyerahan hak milik kendaraan bermotor sebagai akibat perjanjian dua pihak atau perbuatan sepihak atau keadaan yang terjadi karena jual beli, tukar menukar, hibah, warisan, atau pemasukan ke dalam badan usaha. Pemungutan bea balik nama kendaraan bermotor dilakukan pada saat penerbitan surat perintah pengeluaran barang. Undang-Undang Nomor 28 Tahun 2009 pasal 96 sampai 99 tentang pajak dan retribusi daerah menyatakan bahwa, pemungutan pajak dilarang diborongkan, setiap wajib pajak membayar pajak yang terutang berdasarkan surat ketetapan pajak atau dibayar sendiri oleh wajib pajak berdasarkan peraturan perundang-undangan perpajakan, serta wajib pajak yang memenuhi kewajiban perpajakan berdasarkan penetapan Kepala Daerah yang dibayar dengan menggunakan surat ketetapan daerah atau dokumen lain yang dipersamakan. Dokumen lain yang dipersamakan yaitu berupa karcis dan nota perhitungan. Wajib pajak yang memenuhi kewajiban perpajakan sendiri dibayar dengan menggunakan surat pemberitahuan pajak daerah, surat ketetapan pajak daerah kurang bayar, dan surat ketetapan pajak daerah kurang bayar tambahan. Peraturan Daerah Nomor 7 Tahun 2011 tentang pajak daerah pasal 52:

a. Pemungutan pajak dilarang diborongkan.

b. Setiap wajib pajak membayar pajak yang terutang berdasarkan penetapan gubernur atau dibayar sendiri oleh wajib pajak berdasarkan perundang-undangan perpajakan daerah.

c. Wajib pajak yang memenuhi kewajiban perpajakan berdasarkan penetapan gubernur membayar dengan menggunakan surat ketetapan pajak daerah atau dokumen lain yang dipersamakan.

d. Dokumen lain yang dipersamakan berupa karcis atau nota perhitungan.

e. Jenis pajak yang dipungut berdasarkan penetapan gubernur adalah pajak kendaraan bermotor, bea balik nama kendaraan bermotor, dan pajak air permukaan.

Jogiyanto (2008:2) mendefinisikan bahwa sistem menurut buku analisis desain dan informasi dapat dilihat dari dua kelompok pendekatan yaitu, dengan menekankan pada prosedur dan yang menekankan pada komponen atau elemennya yaitu, berdasarkan penekanan prosedur dan berdasarkan penekanan komponen. Committee of Sponsoring Organizations of the Treadway Commission (COSO) framework (2013) menyatakan bahwa pengendalian internal terdiri dari 5 komponen yaitu: lingkungan pengendalian, penaksiran risiko, aktivitas pengendalian, informasi dan akuntansi, dan pemantauan atau monitoring.

Menurut Tunggal (2016:218), pengendalian internal adalah suatu proses yang dijalankan oleh dewan komisaris, manajemen, dan personal entitas lain yang didesain untuk memberikan keyakinan memadai tentang pencapaian 3 golongan. Ponto dan Afandi (2015) menunjukkan bahwa sistem dan prosedur pemungutan pajak daerah telah berjalan dengan baik pada Dinas Pendapatan Daerah Provinsi Sulawesi Utara. Homenta dan Afandi (2015) menemukan bahwa sistem pengendalian penerimaan pajak daerah di Kabupaten Halmahera Utara masih terdapat ketidaksesuaian dengan Peraturan Pemerintah Republik Indonesia Nomor 60 Tahun 2008. Lumentah (2013) menemukan bahwa sistem pemungutan pajak hiburan di kota Manado telah dijalankan dengan baik. Pujiono et al. (2016) menunjukkan bahwa sistem pengendalian intern berpengaruh signifikan terhadap pengelolaan keuangan daerah, dan kinerja pemerintah daerah Maluku Utara, serta pengelolaan keuangan daerah berpengaruh signifikan terhadap kinerja pemerintah daerah Maluku Utara. 


\section{METODE PENELITIAN}

Jenis penelitian yang digunakan dalam penelitian ini adalah penelitian kualitatif yaitu dengan menyajikan data-data yang dapat memberikan gambaran secara umum tentang Badan Pendapatan Daerah Provinsi Sulawesi Utara, serta memberikan gambaran tentang bagaimana sistem dan prosedur pemungutan pajak kendaraan bermotor dan bea balik nama kendaraan bermotor pada Badan Pendapatan Daerah Provinsi Sulawesi Utara. Objek penelitian ini dilaksanakan di Badan Pendapatan Daerah Provinsi Sulawesi Utara yang beralamat di jalan 17 Agustus Nomor 69, Teling Atas, Kecamatan Wanea, Kota Manado, Sulawesi Utara.

Penelitian ini menggunakan data kualitatif yaitu dengan melakukan pengamatan, pencatatan dan wawancara secara langsung di Badan Pendapatan Daerah Provinsi Sulawesi Utara. Sumber data yang digunakan dalam penelitian ini adalah data primer, dimana data yang didapat langsung dari hasil observasi, dokumentasi dan wawancara langsung dengan pihak Badan Pendapatan Daerah Provinsi Sulawesi Utara.

Metode pengumpulan data dalam penelitian ini dikumpul melalui wawancara atau tanya jawab secara langsung ke Badan Pendapatan Daerah Provinsi Sulawesi Utara baik dengan pimpinan atau dengan pegawai mengenai sistem dan prosedur pemungutan pajak kendaraan bermotor dan bea balik nama kendaraan bermotor untuk mendapatkan informasi yang jelas dalam mendukung penelitian ini. Metode analisis data yang digunakan adalah metode deskriptif kualitatif yang berisi data yang nyata atau (fakta) yang di ungkapkan dilapangan untuk memberikan dukungan terhadap apa yang disajikan agar bisa diambil suatu kesimpulan.

\section{HASIL PENELITIAN DAN PEMBAHASAN \\ 4.1. Hasil penelitian}

Berdasarkan hasil wawancara dengan Ibu Apriane Siwi, selaku Kepala Seksi Pelayanan Pajak Kendaraan Bermotor dan Bea Balik Nama Kendaraan Samsat Manado tentang sistem dan prosedur pembayaran manual pajak kendaraan bermotor dan bea balik nama kendaraan bermotor pada Badan Pendapatan Daerah Provinsi Sulawesi Utara menyatakan bahwa apabila wajib pajak ingin membayar ke loket bank yang ada di Samsat Manado, wajib pajak harus membawa nota perhitungan pajak kendaraan bermotor atau bea balik nama kendaraan bermotor yang telah ditanda tangani oleh petugas korektor.

1. Wajib pajak mulai melakukan penyetoran atau pembayaran uang pajak kendaraan bermotor atau bea balik nama kendaran bermotor di loket bank sesuai dengan besaran yang tertera pada nota perhitungan.

2. Petugas bank yang menerima nota perhitungan tersebut dan membubuhkan stempel bukti pelunasan selanjutnya diserahkan kepada wajib pajak.

3. Setelah wajib pajak melakukan penyetoran, wajib pajak dipersilahkan menunggu di loket untuk penyerahan Surat Ketetapan Pajak Daerah dan Surat Tanda Nomor Kendaraan kemudian diserahkan pada petugas pencetakan.

4. Berkas diterima oleh petugas pencetakan untuk menerbitkan Surat Ketetapan Pajak Daerah, Surat Tanda Nomor Kendaraan, dan Tanda Nomor Kendaraan Bermotor.

5. Validasi arsip Surat Ketetapan Pajak Daerah.

Pembayaran melalui Samsat bantu, dimana wajib pajak tidak bisa melakukan pembayaran bea balik nama kendaraan bermotor melalui Samsat bantu, dikarenakan fasilitas Samsat bantu ini hanya dilakukan untuk pembayaran tahunan, sedangkan untuk 5 tahun tidak bisa dilakukan dikarenakan harus ada proses cek fisik kendaraan, dan pada Samsat bantu ini tidak menggunakan fasilitas itu. Pada prosedur pembayaran pajak kendaraan bermotor melalui Samsat bantu ada 7 Samsat bantu yang dijalankan Badan Pendapatan Daerah Provinsi Sulawesi Utara dalam pemungutan pajak kendaraan bermotor salah satunya yaitu 
pembayaran pajak kendaraan bermotor melalui drive thru. Pembayaran tersebut hanya memakan waktu kurang dari 5 menit yaitu :

1. Wajib pajak yang ingin membayar pajak kendaraan bermotor harus membawa berkas asli.

2. Wajib pajak menyerahkan berkas tersebut kepada loket 1 yaitu petugas pendaftaran.

3. Petugas yang ada di loket 1 menerima berkas yang diberikan wajib pajak kemudian petugas mulai menginput/memasukan data dari wajib pajak.

4. Semua Samsat bantu yang salah satunya drive thru ini menggunakan sistem yang menghubungkan antara Samsat bantu dengan Samsat Manado yaitu dengan menggunakan sistem informasi Samsat Sulut yang gunanya agar para petugas Samsat bantu dapat mengetahui/mengecek identitas asli wajib pajak dan berapa nominal pajak yang harus dibayarkan oleh wajib pajak.

5. Wajib pajak dipersilahkan untuk melakukan pembayaran pajak kendaraan bermotor di loket 1 .

6. Setelah wajib melakukan pembayaran, petugas yang berada di loket 1 memberikan berkas kepada petugas loket 2 dan loket 2 akan mencetak notice pajak yang disahkan oleh petugas kepolisian.

8. Petugas kemudian menyerahkan notice pajak atau Surat Tanda Nomor Kendaraan dan berkas tersebut diserahkan kepada wajib pajak.

9. Notice pajak yang dicetak harus difotocopy dan dibawah ke Samsat sebagai arsip.

Pembayaran online ini terdapat 2 cara pembayaran yaitu yang pertama pembayaran melalui ATM dan yang kedua pembayaran melalui Bank SulutGo untuk mempermudah wajib pajak dalam membayar pajak kendaraanya sendiri. Pembayaran online ini mulai dijalankan oleh Samsat Manado pada tahun 2017. Sebelum wajib pajak melakukan pembayaran melalui online tersebut, wajib pajak harus memeriksa nominal pajak yang harus dibayarkan. Informasi mengenai pembayaran dan kode bayar dapat diperoleh melalui Aplikasi Info Pajak Kendaraan Sulut dan bisa juga melalui sms gate away. Setelah wajib pajak melakukan pengecekan melalui aplikasi dan sms gate away, wajib pajak akan mendapatkan kode bayar yang akan ditukarkan. Berikut ini sistem dan prosedur pembayaran melalui ATM dan bank yang ditunjuk yaitu pembayaran melalui ATM (Anjungan Tunai Mandiri), dan pembayaran melalui bank SulutGo.

\subsection{Pembahasan}

Pembayaran pajak kendaraan bermotor dan bea balik nama kendaraan bermotor di Badan Pendapatan Daerah Provinsi Sulawesi Utara berpedoman pada Peraturan Daerah Provinsi Sulawesi Utara Nomor 7 Tahun 2011 pasal 52 ayat 3 mengatakan bahwa wajib pajak yang memenuhi kewajiban perpajakan berdasarkan penetapan Gubernur yaitu membayar dengan menggunakan surat ketetapan pajak daerah atau dokumen lain yang dipersamakan berupa karcis dan nota perhitungan. Wajib pajak dalam melakukan pembayaran pajak yang terhutangnya harus berdasarkan nota perhitungan yang telah ditetapkan oleh petugas korektor. Wajib pajak tersebut harus mengambil nota perhitungan yang telah di tanda tangani oleh petugas korektor dibagian penetapan. Nota tersebut diberikan kepada wajib pajak dan wajib pajak mulai melakukan pembayaran pajak terhutangnya sesuai dengan nominal yang tertera pada nota perhitungan di loket bank Samsat Manado. Petugas di loket bank Samsat yang telah menerima nota perhitungan tersebut akan membumbuhkan stempel bukti pelunasan dan selanjutnya berkas tersebut akan diserahkan kembali kepada wajib pajak. Setelah wajib pajak melakukan penyetoran pajaknya, wajib pajak kemudian dipersilahkan untuk menunggu diloket untuk penyerahan surat ketetapan pajak daerah dan surat tanda nomor kendaraan. Maka dapat disimpulkan bahwa sistem pembayaran manual yang diterapkan oleh Badan Pendapatan Daerah sudah sesuai dengan peraturan yang berlaku karena dalam sistem dan prosedur pembayaran ini sudah menggunakan nota perhitungan. 
Pembayaran pajak kendaraan bermotor dan bea balik nama kendaraan bermotor di Badan Pendapatan Daerah Provinsi Sulawesi Utara berpedoman pada Peraturan Daerah Provinsi Sulawesi Utara Nomor 7 Tahun 2011 Pasal 52 ayat 3 mengatakan bahwa wajib pajak yang memenuhi kewajiban perpajakan berdasarkan penetapan Gubernur membayar dengan menggunakan surat ketetapan pajak daerah atau dokumen lain yang dipersamakan berupa karcis dan nota perhitungan. Jika dilihat dari hasil penelitian yang telah dilakukan oleh Badan Pendapatan Daerah untuk pembayaran melalui Samsat bantu, dimana wajib pajak yang ingin membayar pajak kendaraan bermotornya hanya membawa identitas asli. Wajib pajak kemudian memberikan identitas asli tersebut kepada petugas yang ada di loket 1 untuk memeriksa apakah identitas wajib pajak sesuai atau tidak dan mengecek berapa nominal yang harus dibayarkan wajib pajak dengan menggunakan aplikasi sistem informasi Samsat Sulut. Petugas yang ada di loket 1 ini berperan sebagai petugas penetapan dan petugas korektor. Setelah kelengkapan data telah sesuai dan selesai diperiksa wajib melakukan pembayaran di loket 1, setelah itu berkas tersebut akan diserahkan kepada loket 2 dan loket 2 akan mencetak notice pajak dan membubuhkan cap pengesahan oleh petugas kepolisian. Maka dapat disimpulkan bahwa sistem dan prosedur pembayaran melalui Samsat bantu yang diterapkan oleh Badan Pendapatan Daerah Provinsi Sulawesi Utara belum sesuai dengan peraturan yang berlaku karena dalam sistem dan prosedur pembayaran ini hanya menggunakan identitas asli dan belum menggunakan nota perhitungan.

Pembayaran pajak kendaraan bermotor dan bea balik nama kendaraan bermotor di Badan Pendapatan Daerah Provinsi Sulawesi Utara berpedoman pada Peraturan Daerah Provinsi Sulawesi Utara Nomor 7 Tahun 2011 pasal 52 ayat 3 mengatakan bahwa wajib pajak yang memenuhi kewajiban perpajakan berdasarkan penetapan Gubernur membayar dengan menggunakan Surat Ketetapan Pajak Daerah atau dokumen lain yang dipersamakan berupa karcis dan nota perhitungan. Wajib pajak dalam melakukan pembayaran online kendaraan bermotornya tidak menggunakan surat ketetapan pajak daerah atau nota perhitungan. Pembayaran online ini hanya memerlukan kode bayar yang bisa dilihat atau dicek melalui Aplikasi Informasi Kendaraan Sulut dan sms gate away. Pada via ATM (Anjungan Tunai Mandiri) kode ini dimasukan bersamaan dengan kode wilayah, dan untuk via bank kode bayar ini diberikan kepada petugas bank kemudian petugas bank akan menginput kode tersebut melalui aplikasi web service yang menghubungkan antara pihak bank dan Samsat Manado sehingga pihak bank dapat mengecek identitas dan nominal pajak yang harus dibayarkan. Setelah wajib pajak melakukan penyetoran, petugas bank akan mencetak bukti pembayaran dan diserahkan kepada wajib pajak untuk ditukarkan ke Samsat Manado dan petugas akan mencetak notice pajak dan pengesahan surat tanda nomor kendaraan. Maka dapat disimpulkan sistem dan prosedur pembayaran melaui via online belum sesuai dengan peraturan yang berlaku karena dalam sistem dan prosedur pembayaran ini menggunakan kode bayar dan belum menggunakan nota perhitungan.

Analisis lingkungan pengendalian yang dijalankan oleh Badan Pendapatan Daerah dalam melakukan pemungutan pajak kendaraan bermotor dan bea balik nama kendaraan bermotor harus berpedoman pada Peraturan Daerah Nomor 7 Tahun 2011 tentang pajak daerah, Peraturan Pemerintah Nomor 15 Tahun 2016 tentang ketentuan umum dan tata cara pemungutan pajak daerah dan mengikuti standar operasional prosedur pemungutan yang diberlakukan, apabila didapati pegawai yang tidak jujur atau tidak mengikuti peraturan yang berlaku, maka akan diberi sanksi yang tegas oleh pihak Badan Pendapatan Daerah. Maka dapat dikatakan bahwa sistem dan prosedur yang dilaksanakan telah memadai karena telah sesuai dan memenuhi unsur-unsur konsep lingkungan pengendalian.

Analisis penaksiran risiko yang sering terjadi pada Badan Pendapatan Daerah pada saat melaksanakan pemungutan karena ada beberapa sebab yaitu kesalahan penyampaian informasi. Penyebab terjadi kesalahan seperti ini disebabkan karena kelalaian dan kurangnya 
ketelitian pegawai, sehingga Badan Pendapatan Daerah mengambil kebijakan dengan melakukan pengecekan lagi dokumen dan data. Maka dapat dikatakan bahwa prosedur yang dilaksanakan sudah memadai karena telah memenuhi unsur-unsur konsep analisis penaksiran risiko yang ada.

Analisis aktivitas pengendalian umum pada Badan Pendapatan Daerah Provinsi Sulawesi Utara yaitu dengan adanya sistem informasi untuk sistem pemungutan pajak kendaraan bermotor dan bea balik nama kendaraan bermotor yaitu sistem informasi manajemen daerah maka dapat dikatakan prosedur yang dilaksanakan sudah memadai karena telah memenuhi unsur dan konsep analisis aktivitas pengendalian. Analisis informasi dan komunikasi yang dijalankan Badan Pendapatan Daerah yaitu dengan adanya sistem informasi manajemen daerah, sistem ini digunakan untuk mendapatkan informasi yang berkaitan dengan pendapatan daerah sehingga Sub Bagian Pelaporan dapat mengetahui informasi sampai mana target pendapatan daerah Badan Pendapatan Daerah tercapai, komunikasi yang sangat baik antara pimpinan dengan pegawai dan pegawai dengan masyarakat. Maka dapat dikatakan prosedur yang dilaksanakan sudah memadai karena telah memenuhi unsur dan konsep analisis informasi dan komunikasi. Analisis pemantauan yang dilakukan oleh pegawai di bidangnya untuk memantau proses pemungutan pajak kendaraan bermotor dan bea balik nama kendaraan bermotor apakah sudah dijalankan dengan baik dan sesuai dengan standar operasional prosedur. Kepala Badan Pendapatan Daerah pun juga ikut dalam pemantauan pemungutan pajak kendaraan bermotor dan bea balik nama kendaraan bermotor di lapangan maka dapat dikatakan bahwa prosedur yang dilaksanakan telah memadai karena telah memenuhi unsur konsep analisis pemantauan.

\section{KESIMPULAN DAN SARAN}

\subsection{Kesimpulan}

Melihat dari pembahasan, maka dapat ditarik kesimpulan yaitu sebagai berikut:

1. Pembayaran manual yang telah dilakukan Badan Pendapatan Daerah Provinsi Sulawesi Utara, telah sesuai dengan peraturan yang berlaku, sedangkan untuk pembayaran melalui Samsat bantu dan via online belum sesuai peraturan yang berlaku.

2. Pengendalian internal prosedur pemungutan yang dilakukan Badan Pendapatan Daerah Provinsi Sulawesi Utara sudah memadai dan sudah sesuai dengan konsep pengendalian internal yang berlaku.

\subsection{Saran}

Untuk pembayaran melalui Samsat bantu dan via online (bank) sebaiknya menggunakan nota perhitungan karena apabila koneksi terputus atau mengalami gangguan maka petugas tidak akan bisa menginput data dan tidak akan mengetahui nominal pajak yang harus dibayarkan oleh wajib pajak sehingga proses pembayaran tidak akan berjalan dengan lancar.

\section{DAFTAR PUSTAKA}

COSO. (2013). Internal control integrated framework. Executive summary, North Carolina: Durham.

Damas, A. D. (2017). Pajak daerah dan retribusi daerah. Malang: UB Press.

Homenta, P. C., \& Afandi, D. (2015). Analisis sistem pengendalian internal penerimaan pajak daerah di Kabupaten Halmahera Utara. Jurnal EMBA: Jurnal Riset Ekonomi Manajemen Bisnis dan Akuntansi, 3(3), 744-877. https://ejournal.unsrat.ac.id/index.php/emba/article/view/9622. 
Jogiyanto, H. M. (2008). Analisis dan desain sistem informasi: Pendekatan terstruktur teori dan praktek aplikasi bisnis. Yogyakarta: Andi.

Lumentah, P. L. (2013). Analisis penerapan sistem pemungutan pajak hiburan di Kota Manado. Jurnal EMBA: Jurnal Riset Ekonomi Manajemen Bisnis dan Akuntansi, 1(3), 1049-1059. https://ejournal.unsrat.ac.id/index.php/emba/article/view/2310.

Mardiasmo. (2018). Perpajakan. Yogyakarta: Andi.

Ponto, A. J., \& Afandi, D. (2015). Analisis sistem dan prosedur pemungutan pajak daerah Provinsi Sulawesi Utara. Jurnal EMBA : Jurnal Riset Ekonomi Manajemen Bisnis dan Akuntansi, $3(3)$, 483-607. https://ejournal.unsrat.ac.id/index.php/emba/article/view/9495.

Pujiono, S. D., Sukarno, H., \& Puspitasari, N. (2016). Pengaruh sistem pengendalian intern terhadap pengelolaan keuangan daerah serta kinerja pemerintah daerah (studi di provinsi Maluku Utara). Jurnal Bisnis dan Manajemen Universitas Jember. 10(1), 6881. https://jurnal.unej.ac.id/index.php/BISMA/article/view/5956.

Peraturan Daerah Provinsi Sulawesi Utara Nomor 7 Tahun 2011 Tentang Pajak Daerah.

Purwono, H. (2010). Dasar-dasar perpajakan dan akuntansi pajak. Jakarta: Erlangga.

Siahaan, M. P. (2010). Pajak daerah dan retribusi daerah edisi revisi. Jakarta: Rajawali Pers.

Supramono., \& Damayanti, T. W. (2010). Perpajakan Indonesia mekanisme dan perhitungan. Yogyakarta: Andi publisher.

Tunggal, A. W. (2016). Pengendalian internal dan pencegahan kecurangan. Jakarta: Harvarindo.

Undang-Undang Nomor 28 Tahun 2009 Tentang Pajak Daerah Dan Retribusi Daerah.

Undang-undang Nomor 16 Tahun 2009 Tentang Ketentuan Umum dan Tata Cara Perpajakan. 